\title{
Pollen Morphology of some Species of Genus Ficus L. (Moraceae) from Egypt
}

\author{
S. S. Teleb and ${ }^{2}$ R. M. Salah-El-din \\ ${ }^{I}$ Botany Department, Faculty of Science, Zagazig University, \\ Zagazig and ${ }^{2}$ Botany Department, University College for \\ Women's, Arts, Science \& Education, Ain Shams University, \\ Cairo, Egypt.
}

\begin{abstract}
TN THE PRESENT work, the pollen morphological characters were lextensively studied in 17 taxa from genus Ficus (Moraceae), based on examination with light and scanning electron microscopy. The studied taxa represent three subgenera (Ficus, Sycomorus and Urostigma), collected from three Egyptian Botanical Gardens (Orman, Ain-Shams and Zoo-garden). The obtained results of fundamental and evolutionary significance were: pollen size (less than $20 \mu \mathrm{m}$ ), pollen shape (circular or elliptic), pollen class (vary from di- to triporate), and the pollen surface sculpture (psilate or finely scabrate). The dendrogram produced from the cluster analysis of the characters of pollen grains have been discussed, and shed light on the relationships, similarities and dissimilarities between the studied taxa. Pollen data only does not support macromorphological evidence for the identification of Ficus species.
\end{abstract}

Keywords: Moraceae, Ficus, pollen, morphology, taxonomy, Egypt.

The first and very simple subdivisions of Ficus was proposed by Thunberg in 1786 and adopted by Vahl in 1805 (Berg 2003a). Ficus is the old Latin name of fig (Stearn, 1996), and constitutes one of the largest genera of angiosperms (Frodin, 2004), consisting of about 1000 species from pan-tropical and subtropical origins (Wagner et al., 1999) and form a distinctive monophyletic clade within the family (Judd et al., 1999).

Ficus is represented in wild Egyptian flora by three taxa: F. salicifolia Vahl, $F$. pseudosycomorus Decne and F. carica L. var. rupestris Hausskn. All of which are either of rare or of very rare occurrence (Täeckholm, 1974). Boulos (1999) changed the name of these taxa; F. salicifolia Vahl into $F$. cordata Thunb. subsp salicifolia (Vahl); F. pseudosycomorus Decne into $F$. palmata Forssk., and $F$. carica L. var. rupestris Hausskn. into F. carica L. However, the number is compensated by numerous cultivated taxa that were introduced to Egypt, particularly during the late $19^{\text {th }}$ century and the $1^{\text {st }}$ half of the $20^{\text {th }}$ century. Ficus carica $\mathrm{L}$. is cultivated in Egypt since historic ages.

(Corresponding author email: samirteleb@yahoo.com) 
One of the most widely adopted infrageneric classification of Ficus is that of Corner (1965). In that classification, Ficus is divided into four subgenera (Ficus, Pharmacosycea, Sycomorus and Urostigma), with the functionally dioecious species united under the subgenus Ficus, but in the most recent classification by Berg and Corner (2005), Ficus is divided into six subgenera and a number of sections.

Burn and Mayle (2008) studied pollen morphology of some genera of Moraceae, Urticaceae and Cecropiaceae which were represented in Amazonian rainforest communities. They demonstrated that all grains are isopolar small monads with tectate exine; pores are always circular and some grains exhibit a slightly protrusion or thickening of the exine around the pores (annulus sensu Punt et al., 2007). Sculpturing of the sexine is usually psilate or scabrate. The shape class $(\mathrm{P} / \mathrm{E})$ varies between oblate and subprolate while some genera exhibiting spheroidal characteristics.

El-Ghazali (1989) studied the pollen morphology of Ficus bengalensis, F. inteophyla, F. religosa and F. sycomorus. All are characterized by ellipsoidal, diporate apertures; pores simple open with annulus situated at the opposite ends of the grain, slightly sunken. Exine tectate imperforate of uniform thickness and endexine slightly thicker than ektexine. Collumellae indistinct and sculpturing psilate. Dimentions less than $25 \mu \mathrm{m}$ in long axis or in short axis.

Ficus have species which are occasionally monoporate or triporate (Jago and Boyd, 2003). Khan et al. (2011) reported all of Ficus species had monad and diporate pollens and they showed very little variation in their exine thickness. Ficus pollens tend to have thinner and smoother exine and they tend to become more asymmetric than other genera of Moraceae family.

Little attention has been paid to the pollen morphology of Ficus. Therefore, the present study was conducted to show how far the pollen morphological variations could be used to distinct between the studied taxa of Ficus.

\section{Material and Methods}

In total, 17 taxa including 15 species; one variety and one subspecies from Ficus were examined (Table 1). The samples were collected from three recognized subgenera Ficus, Urostigma and Sycomorus (Corner, 1965) obtained from three Egyptian gardens: Orman Botanical Garden (OBG), Dokky, Giza, Egypt; Ain Shams Botanical Garden (AB), Ain Shams University, Egypt and Zoo-Garden (ZG), Dokky, Giza, Egypt. Identification was verified according to $\mathrm{W}^{3}$ TROPICOS (2008), GRIN (2008) and IPNI (2008).

Egypt. J. Bot., 54, No. 1 (2014) 
TABLE 1. Species collection.

\begin{tabular}{|c|c|c|c|}
\hline No. & Species & Subgenus & Source \\
\hline 1 & $\begin{array}{l}\text { Ficus afzelii G. Don. in J. C. Loudon, Hort. Brit. ed. 1: } 416 . \\
1830=\text { F. saussureana Dc. }\end{array}$ & Urostigma & OBG \\
\hline 2 & F. benghalensis L. in Sp. Pl. 2:1059. $1753=F$. indica L. & Urostigma & OBG \\
\hline 3 & $\begin{array}{l}\text { F. benjamina var. comosa (Roxb.) Kurz in Forest Fl. Burma } \\
\text { 2: } 446.1877\end{array}$ & Urostigma & $\mathrm{AB}$ \\
\hline 4 & $\begin{array}{l}\text { F. cordata Thumb., subsp. salicifolia }(\text { Vahl. })=\text { F. salicifolia } \\
\text { Vahl in Symb. Bot. 1: } 82.1790 .\end{array}$ & Urostigma & $\mathrm{AB}$ \\
\hline 5 & $\begin{array}{l}\text { F. cunninghamii Miq. In Ann. Mus. Bot. Lugd. Bat. iii, 286- } \\
\text { Austral. }\end{array}$ & Urostigma & OBG \\
\hline 6 & $\begin{array}{l}\text { F. deltoidea Jack, In Malayan Misc. 2(7): 71. 1822. =F. } \\
\text { diversifolia Blume. }\end{array}$ & Ficus & $\mathrm{AB}$ \\
\hline 7 & $\begin{array}{l}\text { F. elastica Roxb. ex Hornem in Hort. Bot. Hahn. Suppl. } 7 . \\
1819=\text { F. decora hort. }\end{array}$ & Urostigma & BGA \\
\hline 8 & $\begin{array}{l}\text { F. infectoria } \text { Roxb. In Ann. Bot. Gard. Calcutta, i. 1. t. } 75, \\
84(1887)=F \text {. virens Aiton. }\end{array}$ & Urostigma & ZG \\
\hline 9 & $\begin{array}{l}\text { F. laurifolia Hort. ex Lam., In Encycl. Meth. (Bot.) 2: } 495 . \\
\text { 1786. }=F . \text { inspida } \text { wika }=F . \text { glabrata } \text { H. B. K. }=F . \\
\text { anthelemintica Mart }\end{array}$ & Urostigma & ZG \\
\hline 10 & $\begin{array}{l}\text { F. macrophylla Desf. ex Pers. In Syn. Pl. 2: 609. } 1807=F \text {. } \\
\text { magnolioides Borzi }\end{array}$ & Urostigma & OBG \\
\hline 11 & $\begin{array}{l}\text { F. mysorensis B. Heyne ex Roth in J. J. Roemer \& J. A. } \\
\text { Schultes, Syst. Veg. 1: 508. 1817(A. W. Roth, Nov. Pl. sp. } \\
390.182=\text { F. drupacea var. pubescens (Roth) corer }\end{array}$ & Urostigma & OBG \\
\hline 12 & $\begin{array}{l}\text { F. platypoda (Miq.) A.Cunn ex Miq. In, Ann. Mus. Bot. } \\
\text { Lugduno-Batavum 3: 287. } 1867 \text { = Urostigma platipodum. }\end{array}$ & Urostigma & OBG \\
\hline 13 & $\begin{array}{l}\text { F. racemosa Wall-Cat. } 1799=F \text {. glomorata Roxb. In Pl. } \\
\text { Coromandel 2: } 13, \text { t. } 123 \text {. }\end{array}$ & Sycomorus & OBG \\
\hline 14 & F. religiosa L. in Sp. Pl. 2: 1059. 1753 & Urostigma & $\mathrm{AB}$ \\
\hline 15 & F. retusa L. = F. nitida Thunb. In Ficus 10. 1786. & Urostigma & $\mathrm{AB}$ \\
\hline 16 & $\begin{array}{l}\text { F. spragueana Mildbr. \& Burret in, Bot. Jahrb. Syst. 46: } 253 . \\
1911 .\end{array}$ & Urostigma & OBG \\
\hline 17 & F. sycomorus L. In Sp. Pl. 1059. 1753. & Sycomorus & OBG \\
\hline
\end{tabular}

Fresh material was used for all the sampled species and pollen extraction method was prepared according to Moore et al. (1991). The dimensions of the polar axis $(\mathrm{P})$, equatorial axis $(\mathrm{E})$, pore diameter and the ratio of polar and equatorial axis $(\mathrm{P} / \mathrm{E})$ were calculated using the Light Microscopy (LM). The mean value $(\mathrm{x})$ of 20 counts, the range of each parameter and the ratio of polar and equatorial axis (P/E) was calculated (Table 2). A standard x100 phase oil immersion objective was used with an $\mathrm{X}_{16}$ photo eye piece. 
To obtain the maximum amount of systematic data from SEM studies of pollen, both acetolyzed ana non-acetolyzed materials were studied. Valuable systematic characters may be lost in acetolysis and true pollen shape may be greatly changed. Study of fresh (non acetolyzed pollen) can greater insight into the functional significance of pollen characters which, in turn, can contribute to better systematic treatment (Harley and Ferguson, 1990).

Scanning Electron Microscopy (SEM) examination was done by two models of SEM at different official centers: (1) A JEM-1200 EX II EL Micrographs with a JEOL UHR Camera 90561 Japan 6X7 cm Adapter and JFC-1100 E Ion Sputter Coated in Central Lab at Faculty of Science, Ain Shams University, Cairo, Egypt; (2) A JOEL JSM-25 SII SEM and JFC-1100 E, Ion Sputtering Device at Faculty of Science, Alexandria University, Alexandria, Egypt. The terminology follows that of Punt et al. (2007).

Pollen morphology was analyzed using the NTSYS-pc program version 2.02 (Exeter Software, NY, USA; Rohlf, 1998). The results were presented in dendrogram which have been discussed to shed light on the relationships, similarities and dissimilarities between the studied taxa. The similarity matrix was used in the cluter analysis by using the NTSYS-pc software version 2.02 (Exeter Software, NY, USA; Rohlf, 1998). This method is known as Unweighted Pair Group Method using Arithmatic Average (UPGMA) using Sequential Agglomerative, Hierarchical and Nested cluster (SAHN) (Sneath and Sokal, 1973).

\section{Results and Discussion}

The variation in the shape class as showing in Table 2: Prolate; $\mathrm{P} / \mathrm{E}=2-1.33$ (8:4-8:6); in Ficus afzelii, F. benjamina v. comosa, F. cunnunghamii, $F$. deltoidea, $F$. infectoria, $F$. laurifolia, $F$. religiosa and $F$. sycomorus. Subprolate; $\mathrm{P} / \mathrm{E}=1.33-1.14$ (8:6-8:3), in Ficus benghalensis, F. mysorensis, $F$. racemosa, $F$. cordata and $F$. spragueana. Prolate spheroidal; $\mathrm{P} / \mathrm{E}=1.14-1.00$ (8:7-8:8), in Ficus elastica, F. macrophylla, F. platypoda and F. retusa.

The pollen grain shape is ellipsoidal in the following Ficus species: afzelii, cunninghamii, platypoda and religiosa (Table 2; Plate1; 1, 2, 9, 21, 22 \& 26). While it is ellipsoidal and triangular; in benghalensis, benjamina var. comosa, deltoidea, elastica, racemosa, infectoria, laurifolia, macrophylla, mysorensis, retusa, cordata and sycomorus (Table 2; Plate1; 3-8, 10-20,23-35 \& 27-30). From the obtained data, it was found that the use of the pollen shape character in evaluating the phylogenetic relationships between the studied taxa is of little value; this is in agreement with Scotland (1992a, b and 1993).

Egypt. J. Bot., 54, No. 1 (2014) 
POLLEN MORPHOLOGY OF SOME SPECIES ...

Egypt. J. Bot., 54, No. 1 (2014) 

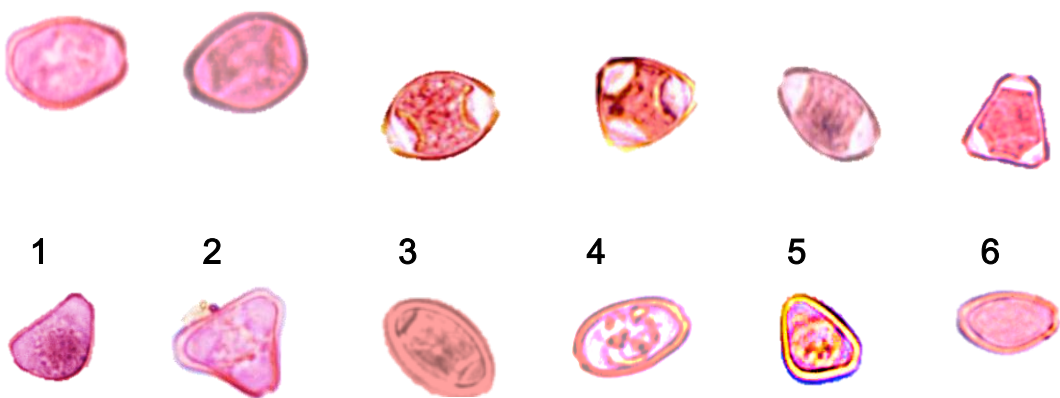

3

4

5

6
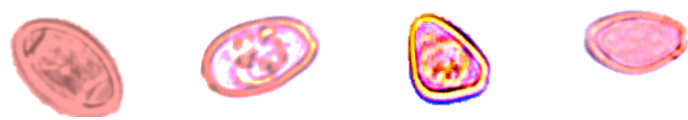

7

8

9

10

11

12
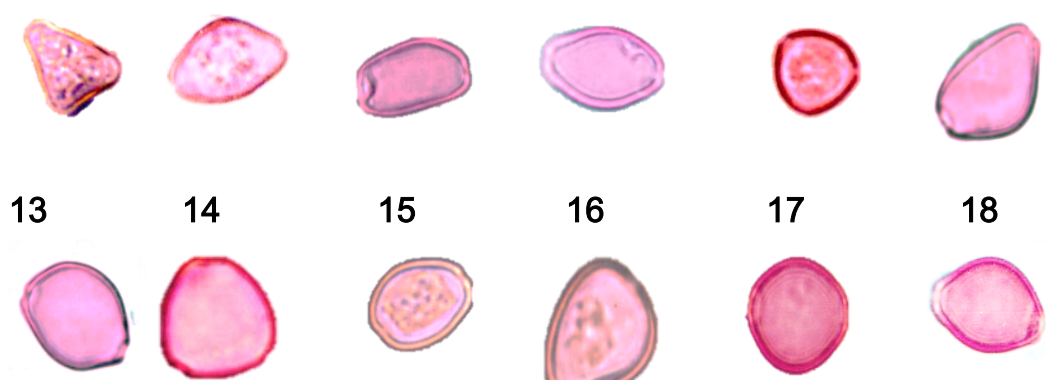

15

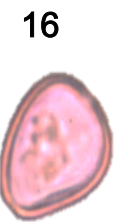

17

18
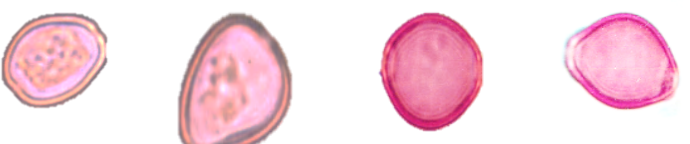

\section{9}

20

21

22

23

24
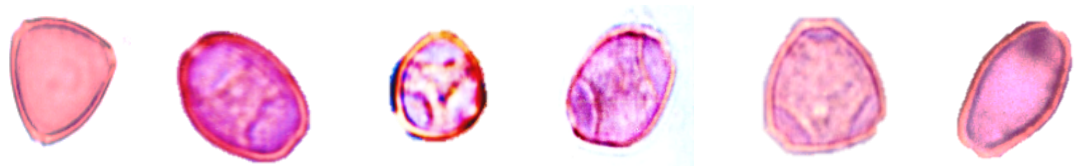

25

26

27

28

29

30

Plate I. 1-30: LM X1600. Pollen morphology: 1, 2. Ficus afzelii; 3, 4. F. benghalensis; 5, 6. F. benjamina var. comosa; 7, 8. F. cordata subsp. salicifolia ; 9. F. cunninghamii; 10, 11. F. deltoidea; 12, 13. F. elastica; 14. F. infectoria; 15, 16. F. laurifolia; 17. F. macrophylla; 18, 19, 20. F. mysorensis; 21, 22. F. platypoda; 23, 24, 25. F. racemosa; 26. F. religiosa; 27. F. retusa; 28, 29. F. sperguana, 30. F. sycomorus.

Regarding dimensions (Table 2) and according to the length of the longest grain axis; whatever this axis is polar or equatorial, all investigated pollen grains are small sized (less than $20 \mu \mathrm{m}$.); this is in agreement with (Kremp, 1965; Bank et al., 2000; Ueckermann and Rooyen, 2000). The pollen aperture which recorded in the current study was porate type. Concerning the number of apertures the obtained results showed that it was diporate in $F$. afzelii, F. cunninghamii, $F$. platypoda and $F$. religiosa (Table 2; Plate I; 3 Plate II, 1, 13 \& 16) while it was diporate and triporate in the rest of the studied taxa (Table 2; Plate I; 3 \& 4 - Plate II, 3, 4, 10 \& 11). Jago and Boyd (2003) reported that Ficus have species which Egypt. J. Bot., 54, No. 1 (2014) 
are occasionally monoporate or triporate, while Khan et al. (2011) studied some Ficus species had diporate.

Moore et al. (1991) recorded that the increased number of apertures provides a better opportunity for the pollen tube to emerge close to the stigma surface than does a single one. The obtained results as in Table 3 showed that the studied taxa grouped according to the pore width into three categories. Pore width narrow $(1.2-1.4 \mu \mathrm{m})$ in $F$. deltoidea, $F$. infectoria, $F$. laurifoila, $F$. retusa and $F$. platypoda. Relatively narrow (1.5-2 $\mu \mathrm{m})$ in $F$. cunninghamii, $F$. elastica, $F$. racemosa, $F$. macrophylla, $F$. mysorensis, $F$. religiosa and $F$. sycomorus. Relatively broad (2.1-3.2 $\mu \mathrm{m})$, in $F$. afzelii, $F$. benghalensis, $F$. benjamina var. comosa, $F$. cordata and $F$. sperguana.

Membrane texture of apertures in all the studied taxa was glabrous and surface level unsunken in three taxa $(F$. cunninghamii, $F$. deltoidea and $F$. racemosa (Table 3; Plate II; 6, 7, 8 \& 12) while it was slightly sunken; in the remaining 14 taxa.

Pore visibility is indistinct in $F$. benjamina var. comosa, $F$. infectoria, $F$. platypoda, $F$. religiosa and $F$. sycomorus, on the other hand it appeared distinct in the remaining 12 taxa. Pore shape more or less elliptic; in $F$. benghalensis, $F$. benjamina v. comosa, $F$. cunninghamii, $F$. cordata, $F$. spragueana and $F$. sycomorus; more or less circular; in the remaining studied 11 taxa (Table 3). Columellae (LM) indistinct and tectum tectate-imperforate.

The characters of exine sculpturing as revealed by SEM is considered a fundamental character used in the identification and delimitation between the taxa under investigation._Sculpturing was psilate in $F$. afzelii, $F$. cunninghamii, $F$. elastica, F. infectoria, F. macrophylla, F. mysorensis, F. platypoda, F. religiosa and F. sycomorus (Table 3; Plate III; $1,6 \& 8$ ). Yet, it was finely scabrate in the remaining studied 8 species (Table 3; Plate III; 2, 3, 4, 5 \&7).

The findings of the study revealed that pollen morphological characters such as the surface sculpturing type, pollen size, shape and outline are mostly useful in distinguishing the studied taxa, but they do not provide strong evidence for the infrageneric delimitation of the genus.

The data collected so far were not sufficient to offer hypotheses on the possible evolutionary trends in the pollen of Ficus as a whole. However, the following subsequent characters were considered to show the magnitude of these characters as being primitive versus advanced. Elliptical shape of pollen grains was considered primitive versus angular (advanced). Porate could be considered as more advanced, the diporate versus triporate (advanced), the greater number of apertures the better the opportunity of the pollen. The leveled aperture is considered primitive than the sunken aperture (advanced). The evolutionary trends of aperture shape from circular versus elliptic, which the elliptic was considered the advanced form. Concerning the pollen sculpturing, the psilate pattern (sculpture less) is primitive, where the ornamented patterns are considered the advanced state (Waker and Doyle 1975). The obtained data 
referred to a degree of advancement in the pollen criteria; the members of the $F$. afezelii, $F$. religiosa, $F$. platypoda and $F$. cunninghamii have lowest grades and occupied a primitive position. 


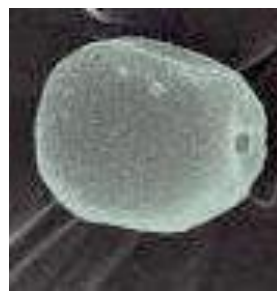

1

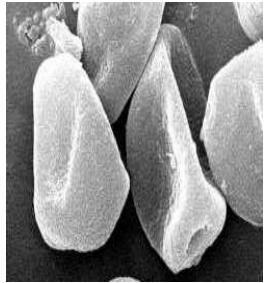

5

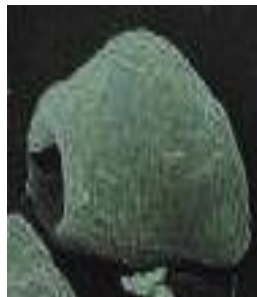

9

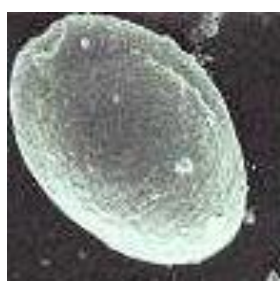

13

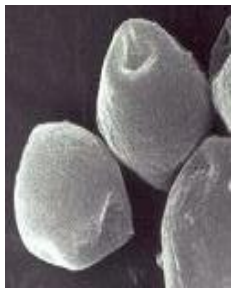

2

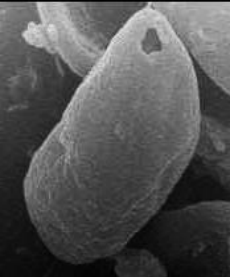

6

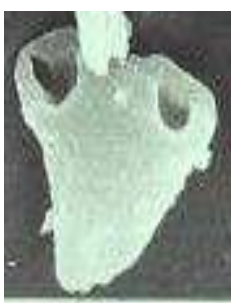

10

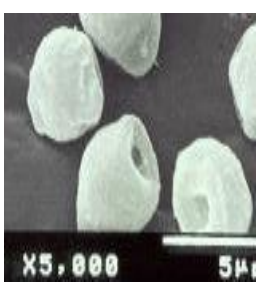

14

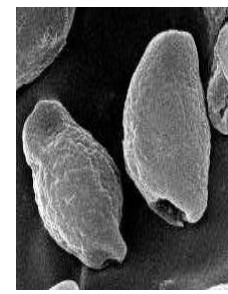

3

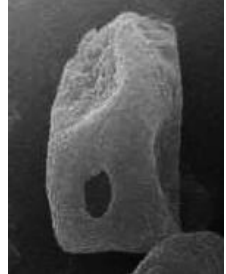

7

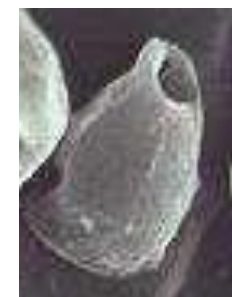

11

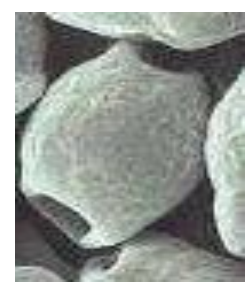

15

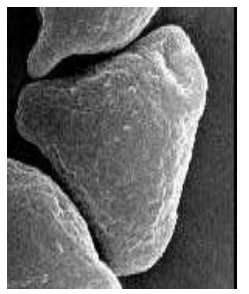

4

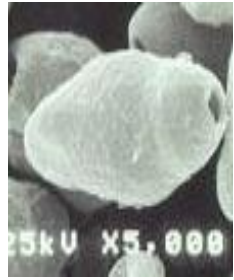

8

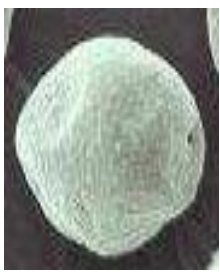

12

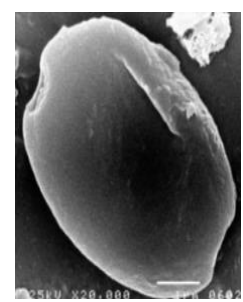

16

Plate II. 1-16 SEM X5000: 1. Ficus afzelii; 2. F. benghalensis; 3, 4. F. benjamina var. comosa; 5. F. cordata subsp. salicifolia ; 6, 7. F. cunninghamii; 8. F. deltoidea; 9. F. laurifolia; 10, 11. F. macrophylla; 12. F. racemosa; 13. F. religiosa; 14. F. retusa; 15. F. sperguana, 16. F. sycomorus. 

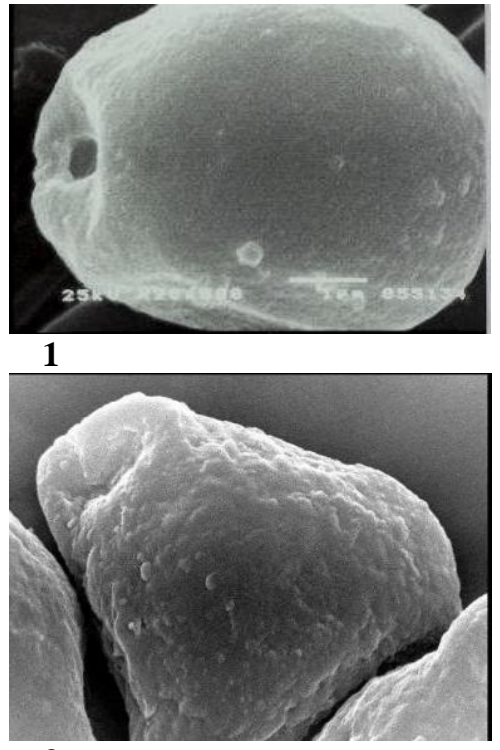

3

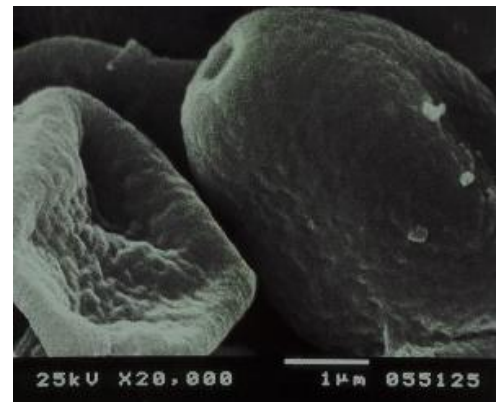

5

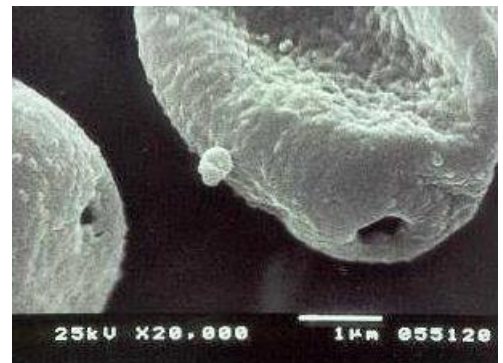

7

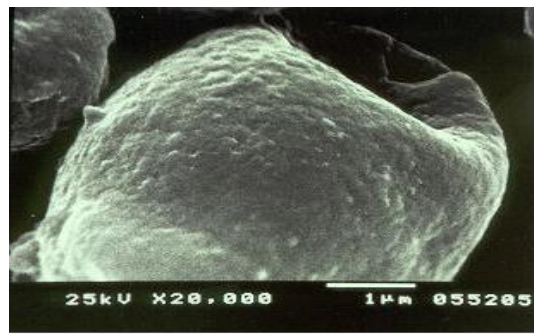

2

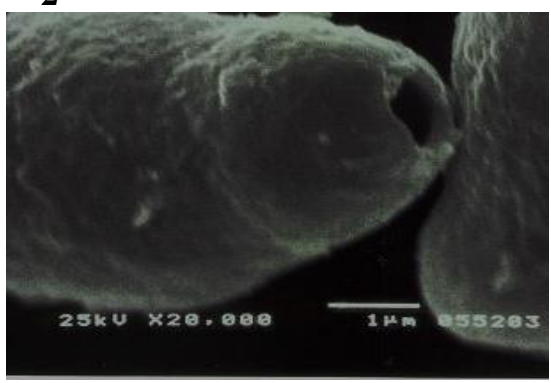

4

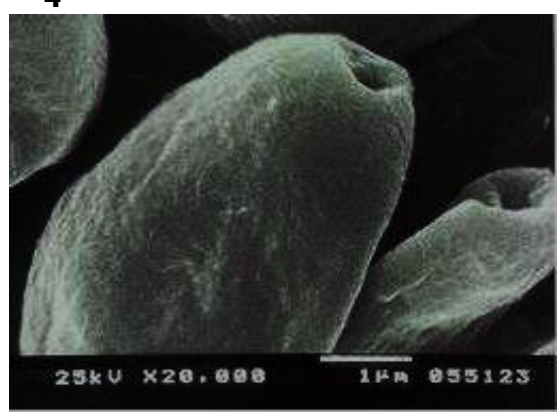

6

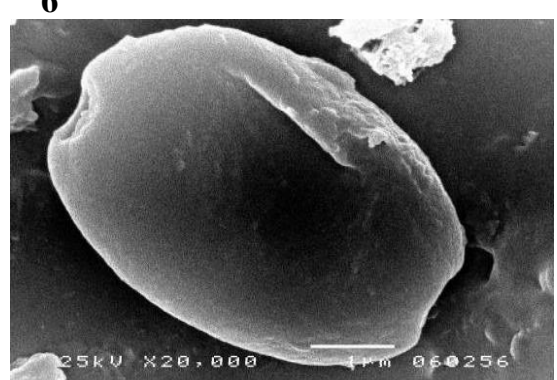

8

Plate III. Fig. 1-8 SEM x20000: Pollen morphology: 1. Ficus afzelii; 2. F. benghalensis; 3. F. benjamina var. comosa; 4. F. deltoidea; 5 F. laurifolia; 6. F. mysorensis; 7. F. racemosa; 8. F. sycomorus. 
The pollen morphology does not appear to be particularly useful as a taxonomic technique in the identification of Ficus species.

Numerous studies were made on genus Ficus to clarify the phylogenetic relationships and evolution in certain subgenera, sections and lower taxonomic ranks, utilizing data sets from entirely different criteria as macromorphology (Berg and Corner, 2005; Chen and Chen, 2005), micromorphology (Dixon, 2002; Neves et al., 2002; Alejandra and José, 2004; Sonibare et al., 2006), chemotaxonomy (Pistelli et al., 2000; Sharaf et al., 2000; Sandabe et al., 2006; Andrzej et al., 2007), reproductive biology (Douglas et al., 2004; Weiblen, 2004), molecular criteria (Noth et al., 1996; Weiblen, 2000; Anuntalabhochai et al. 2008) and chromosome studies (Azizian and Sonboli, 2001). However, the obtained results were different; none of these studies have reached a conclusive result in determining the inter-specific relationships between the taxa of Ficus. This may be attributed to the following facts:

1- The investigated taxa in a particular study were unlike that included in another study, utilizing different criteria (Heywood, 2001). So they could not be compared objectively, this fact is particularly true when dealing with exceptionally large and diverse genera as in the case of Ficus.

2- Only a few number of Ficus taxa were studied since new ones are still discovered annually (Berg, 2002; Van Noort et al., 2007), thus continuously changing our view on the relationships within the taxa of the genus.

\section{Numerical analysis}

The dendrogram produced from the cluster analysis of 18 palynological character states (Fig. 1) shows that the taxa are divided into two main clusters at similarity level 0.42 . The first cluster includes $F$. cunninghamii at similarity level $0.66, F$. platypoda, $F$. religiosa and $F$. afzelii at similarity level 0.77 . The second cluster is divided into two groups. The first group (Gr. I) includes $F$. benjamina v. comosa which splits off other species in the same group at similarity level 0.77 and $F$. spragueana, F. cordata subsp salicifolia and $F$. benghalensis which are closely related to each other at similarity level 1.00. The second group (Gr. II) also is divided into two sub-groups; the first sub-group consists of $F$. racemosa (subgenus Sycomorus) at similarity level $0.66, F$. retusa (subgenus Urostigma) at similarity level $0.88, F$. laurifolia (subgenus Urostigma) and $F$. deltoidea (subgenus Ficus) at similarity level 0.88 . The second sub-group included $F$. sycomorus (subgenus Sycomorus) and $F$. infectoria (subgenus Urostigma) at similarity level $0.77, F$. mysorensis at similarity level 0.88 and $F$. macrophylla and $F$. elastica which are also closely related to each other at similarity level 1.00. The dendrogram illustrates the relationship between $F$. deltoidae (subgenus Ficus) with $F$. laurifolia and F. retusa (subgenus Urostigma). While the two studied taxa of subgenus Sycomorus (F. racemosa and F. sycomorus) were separated in 2 different subgroups and showed relations with the taxa of subgenus Urostigma. Also studied taxa of subgenus Ficus (F. deltoidae) possessed relation with members of subgenus Urostigma. 


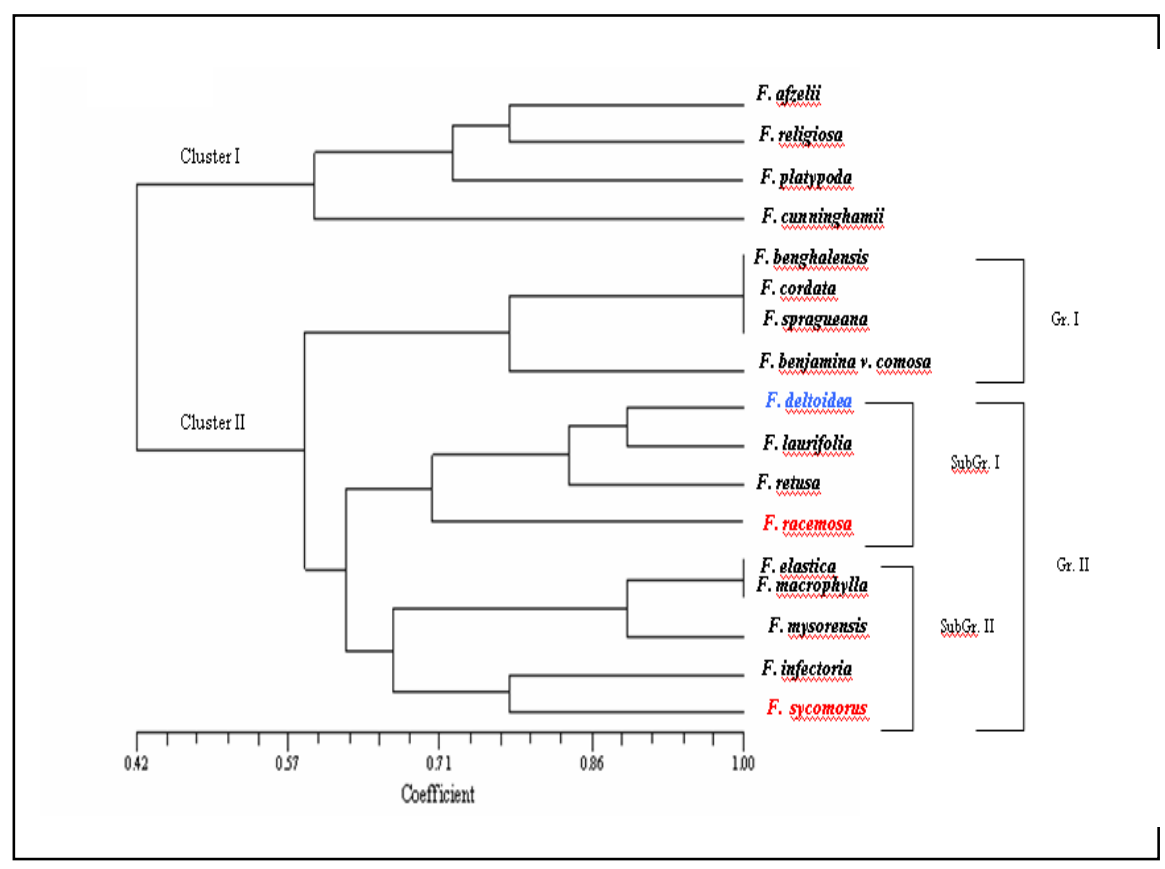

Fig.1. UPGMA- dendrogram based on 18 palynological characters illustrating similarity between the studied taxa.

Acknowledgements: The authors would like to express their gratitude to late Professor Dr. Sayed F. Khalifa (Prof. of Plant Taxonomy and Flora, Ain Shams University), Prof. Dr. Mohamed E. Tantawy (Prof. of Plant Taxonomy and Flora, Head of Botany Dept., Faculty of Science, Ain Shams University), and Prof. Dr. Thoria R. Mohamed (Prof. of Cell Biology and Genetics \& Head of Botany Dept., University college for Women's; Art, Science and Education, Ain Shams University) for suggesting, providing facilities, faithful support and continuous encouragement.

\section{References}

Alejandra, Q. and José, L. (2004) Anatomy and histochemistry of the bark of five species of Moraceae. Polibotanic.,17, 15-38.

Andrzej, M., Ewa, C., Le xuan C., Tran, B., Ewa, S. and Tadeusz, C. (2007) The search for polyprenols in dendroflora of Vietnam. Acta Biochimica Polonica, 54(4), 727-732.

Egypt. J. Bot., 54, No. 1 (2014) 
Anuntalabhochai, S., Phromthep, W., Sitthiphrom, S., Chundet, D. and Cutler, R. (2008) Phylogenetic diversity of Ficus species using HAT-RAPD markers as a measure of genomic polymorphism. Open Agriculture Journal, 21, 62-67.

Azizian, D. and Sonboli, A. (2001) Chromosome counts for five species of moraceae from Iran. Iranian J. Bot. 9(1), 103-106.

Bank, F. H., bank, M., and Balkwill, K. (2000) Electrophoretic evidence for an under scribed species of Barleria L. Afr. J. Bot., 66(1), 22-27.

Berg, C. C. (2002) "Ficus baola" a new species of Ficus subgenus Urostigma section Malvanthera (Moraceae) from the Solomon Islands. Blumea. 47(2), 315-317.

Berg, C. C. (2003a) "Flora Malesiana precursor for the treatment of Moraceae" I: The main subdivision of Ficus; the subgenera Blumea 48, 167-178.

Berg, C. C. and Corner, E. J. H. (2005) Moraceae - "Ficus. Flora Malesiana" Series I 17(2), 71 .

Boulos, L. (1999) "Flora of Egypt" (Azollaceae-Oxalidaceae). Al-Hadara Publishing, Cairo, Egypt, Vol. (1), 14 -16.

Burn M. J. and Mayle E. F. (2008) Palynological differentiation between genera of the Moraceae family and implications for Amazonian palaeoecology Review of Palaeobotany and Palynology, 149, 187-201.

Chen, C. and Chen, Y. (2005) Study on laminar hydathodes of Ficus formosana (Moraceae) I. Morphology and ultra-structure. Bot. Bull. Acad. Sin., 46, 205-215.

Corner, E.J.H. (1965) Checklist of Ficus in Asia and Australasia with keys to identification. Gardens Bulletin Singapore, 21, 1-186.

Dixon, D. J. (2002) Short note: Ficus rubiginosa f. glabrescens (F.M. Bailey): a new taxonomic status for an old Bailey name. Austral. Syst. Bot., 15(2), 245.

Douglas, W., Jo, R., Emmanuelle, J., Edward, A., Stephen, G., James, M., Jamie, C. and Weiblen, D. (2004) Oviposition strategies, host coercion and the stable exploitation of figs by wasps. Proc. Biol. Sci., 1544, 1185-1195.

El-Ghazali G. (1989) "A study on the pollen Flora of Sudan with special reference to pollen identification". University of Bergen Botanical inistitute, p $215-216,320$.

Frodin, D. G. (2004) History and concepts of fig plant genera. Taxon, 53, 753-776.

GRIN: Germplasm Resources Infprmation Network online Database (2008) USDA, ARS, National Resource Lab. Beltsuille, Maryland. http://www.ars-gin.gov./ var/apache/ege-bin/npgs/html/. 
Harley, M. M. and Ferguson, I. K. (1990) "The role of the SEM in pollen morphology and plant systematics". Scanning Electron Microscopy in Taxonomy and Functional Morphology (Ed. D. Claugher) Sys. Assoc. Special Issue, 41, 45-68, Claredon Press, Oxford.

Heywood, V. H. (2001) Floristics and Monongraphy, an uncertain future. Taxon, 50(2), 361-380.

IPNI: International Plant Names Index (2008) Marck Jackson Application Manager Royal Botanic Gardens Kew. http://www.ipni.org/index.html.

Jago L. C. F. and Boyd W. E. (2003) A GIS Atlas of the fossil Pollen and Modern Records of Ficus and related species for island Southeast Asia, Australia and the western Pacific. Institute of Australian Geographers, 41(1), 58-72.

Judd, W. S., Cambell, C. S., Kellogg, E. A. and Stevens, P. F. (1999) "Plant systematics, a phylogenetic approach". Sinauer Associates. Inc. pp. 72, 73, 291 - 291, $302-304$.

Khan K. Y., Khan M. A., Shah G. M., Ahmed M., Munir M., Hussain I., Fazal H., Mazari P., Ali B., Seema N. and Bokhari S. H. (2011) Palynological characterization of some species of Ficus L. Pakistan Journal of Medicinal Planta Research, 5(20), 5067-5070.

Kremp, G. O. W. (1965) "Morphologic Encyclopodia of Palynology". An international collection of definitions and illustrations of spores and pollen. The University of Arizona Press Tucson.

Moore, P. D., Webb, J. A. and Collinson, M. E. (1991) "Pollen Analysis" $2^{\text {nd }}$ ed., Blackwell Scientific Publications, Oxford, London. 62-82 \& 165.

Weves, L. J., Mello Filho L.E. and Carauta J.P. (2002) Anatomia de Ficus (Moraceae) aplicada a taxonomia. Albertoa, N.S., 7, 45-52.

Noth, M., Feindt, F., and Muhlbach, H. P. (1996) Extraction of DNA and randam amplified polymorphic DNA (RAPD) analysis of Ficus carica L. and Ficus sycomorus L. Mitt. Inst. Allg. Bot. Hamburg, 26, 153-160.

Pistelli, L., Chiellini, E.E., Morelli, I. (2000) Flavonoids from Ficus pumila. Biochem. Syst. Ecol., 8(3), 287-289.

Punt, W., Hoen, P. P., Blackmore, S., Nilsson, S. and Le Thomas, A. (2007) Glossary of pollen and spore terminology. Review of Palaeobotany and Palynology, 143, 1-81.

Rohlf, F. J. (1998) NTSYS-pc. Numerical taxonomy and multivariate analysis system, version 2.02 Exeter Software, Setauket, New York, USA.

Sandabe, U. K., Onyeyili, P. A. and Chibuzo, G. A. (2006) Phytochemical screening and effect of aqueous extract of Ficus sycomorus L. (Moraceae) stem bark on muscular activity in laboratory animals, J. of Ethnopharmacology, 104, 283-285.

Scotland, R. W. (1992a) Pollen morphology of Andrographideae (Acanthaceae). Review of Palaeobotany and Palynology, 72, 229-243.

Egypt. J. Bot., 54, No. 1 (2014) 
Scotland, R.W. (1992b) Systematics similarity and Acanthaceae pollen morphology. Bot. J. Linn. Soc., 109, 529-541.

Scotland, R. W. (1993) Pollen morphology of Contorate (Acanthaceae). Bot. J. Linn. Soc., 111, 471-504.

Sharaf, M., Abu-Gabal, N. S. and El- Ansari, M.A. (2000) Exudate flavonoids from Ficus altissima. Biochem. Syst. Ecol., 28(3), 291-293.

Sneath, P. H. and Sokal, R. R. (1973) "Numerical taxonomy Freeman". San Francisco. P. 573.

Sonibare, M. A., Jayeola, A. A. and Egunyomi, A. (2006) Comparative leaf anatomy of Ficus Linn. Species (Moraceae). Nigeria. J. of Applied Sci., 6, 3016-3025.

Stearn, W.T. (1996) "Stearn's Dictionary of plant Names for Gardens". A Handbook on the origin and Meaning of the botanical names. Cassell publishers. London PP.140.

Täeckholm, V. (1974) "Student's Flora of Egypt", $2^{\text {nd }}$ ed., Cairo, Cairo University.

Ueckermann, C. and Van Rooyen, M. W. (2000) Insect pollination and seed set. In four ephemeral plant species. Namaqual and S. Afr. J. Bot., 66(1), 28-30.

Van Noort, S., Gardiner, A. and Tolley, K. (2007) New records of Ficus (Moraceae) species emphasize the conservation significance of inselbergs in Mozanbique. South African J. of Bot., 73, 642-649.

W $^{3}$ TROPICOS (2008) Nomenclatural and Specimen Database of the Missouri Botanical Garden. http://www.mobot.org/w3t/search/vast.

Wagner, W. L., Herbst, D. R. and Sohmer, S. H. (1999) "Manual of the Flowering Plants of Hawaii". 2 vol. Bishop Museum Special Publication 83, University of Hawai'i and Bishop Museum Press, Honolulu, HI.

Waker, J. W. and Doyle, J. A. (1975) The bases of angiosperm phylogeny: palynology. Ann. Missouri Bot. Gard., 62, $664-723$.

Weiblen, G. D. (2000) Phylogenetic relationships of functionally dioecious Ficus (Moraceae) based on ribosomal DNA sequences and Morphology. American J. Bot., 87(9), 1342-1357.

Weiblen, G. D. (2004) Correlated evaluation in fig pollination. Syst. Biol., 53(1), 128-139.

(Received $1 / 10 / 2013$

accepted $18 / 12 / 2013)$ 


\section{مورفولوجيا حبوب القاح لبعض انواع جنس فيكس (الفصيلة

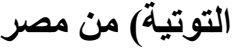 \\ سمير سالم طلب' و ريم محمد صلاح الاين' النّات

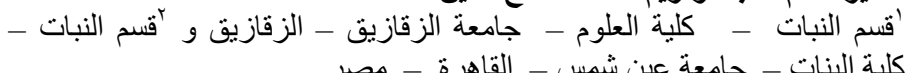

فى هذه الدر اسة تم در اسة مورفولوجيا حبوب القاح لسبعة عشر نو عاً من جنس فيكس وليكس

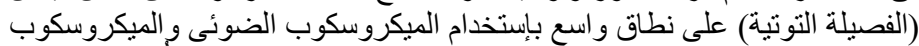

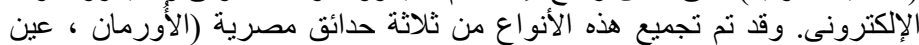

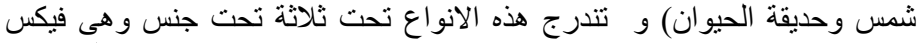
Ficus

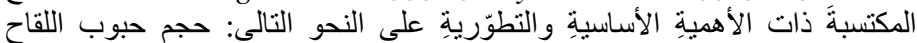

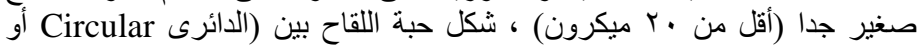

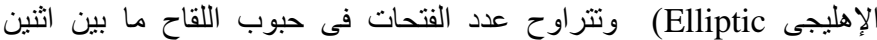

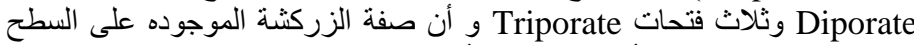

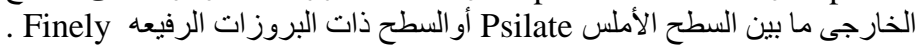
scabrate

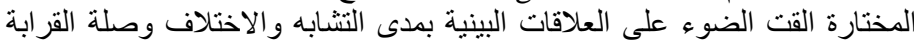

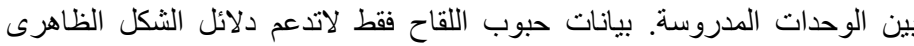
لتعريف جنس الفيكس. 